\title{
Determination of Cysteine by Discoloration Spectrophotometry using Copper( II)-Bis-Cyclohexanone Oxalydihydrazone
}

\author{
Changqing Tu and Xinrong Wen* \\ School of Chemistry and Environment, Jiaying University, Meizhou, Guangdong 514015, China \\ Guangdong Provincial Key Laboratory of Conservation and Precision Utilization of Characteristic Agricultural Resources in \\ Mountainous Areas, Jiaying University, Meizhou, Guangdong 514015, China
}

\begin{abstract}
In the alkaline medium of $\mathrm{pH}=9.18, \mathrm{Cu}^{2+}$ can be reduced to $\mathrm{Cu}^{+}$by the sulfhydryl (-SH) of cysteine, and it result in the decrease the amount of $\mathrm{Cu}^{2+}$ in the system. The decrement of $\mathrm{Cu}^{2+}$ is directly proportional to the addition of cysteine, then using bis-cyclohexanone oxalyldihydrazone (BCO) as chromogenic reagent for $\mathrm{Cu}^{2+}$ to determinate the content of cysteine indirectly by discoloration spectrophotometry. A new method for the determination of cysteine by discoloration spectrophotometry using Copper( II)-BCO has been established. The influencing factors of the determination of cysteine is investigated. The results show that the maximum absorption wavelength of chromogenic system was 602 $\mathrm{nm}$, in the range of $0.008000 \sim 0.06800 \mathrm{mg} / \mathrm{mL}$, the linear relationship between the decrease of absorbance and the mass concentration of methimazol is $\mathrm{A}=0.2162+2.4824 \mathrm{C}(\mathrm{mg} / \mathrm{mL})$, and the linear correlation coefficient is $\mathrm{r}=0.9959$. The method has been applied to the determination of cysteine in food, and the results are basically consistent with those determined by pharmacopoeial method.
\end{abstract}

\section{Introduction}

Cysteine(the molecular structure is shown in Figure 1) is an indispensable amino acid containing sulfhydryl in human body. It plays important roles in protein synthesis, detoxification metabolism and so on. Cysteine deficiency can causes many symptoms, such as children grow slowly, liver damage sleepiness and so on. However, at higher than normal levels, it turns to cause the cardiovascular diseases, osteoporosis, etc. Therefore, it is important to establish a simple method for the determination of cysteine.

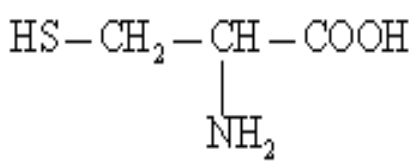

Fig.1. The molecular structure of cysteine

So far, Various different methods have been applied for the determination of cysteine, such as colorimetric determination[1], diffuse reflectance spectroscopy[2], electrochemiluminescence[3], fluorescence detection[45], HPLC[6], etc.

In the alkaline medium of $\mathrm{pH}=9.18, \mathrm{Cu}^{2+}$ can be reduced to $\mathrm{Cu}^{+}$by the sulfhydryl (-SH) of cysteine, and it result in the decrease the amount of $\mathrm{Cu}^{2+}$ in the system. The decrement of $\mathrm{Cu}^{2+}$ is directly proportional to the addition of cysteine, then using bis-cyclohexanone oxalyldihydrazone $(\mathrm{BCO})$ as chromogenic reagent for $\mathrm{Cu}^{2+}$ to determinate the content of cysteine indirectly by discoloration spectrophotometry. A novel method for the determination of cysteine by discoloration spectrophotometry using Copper( II )-BCO is established. The maximum absorption wavelength of chromogenic system is $602 \mathrm{~nm}$, in the range of $0.008000 \sim 0.06800 \mathrm{mg} / \mathrm{mL}$, the linear relationship between the decrease of absorbance and the mass concentration of methimazol is $\mathrm{A}=0.2162+2.4824 \mathrm{C}$ $(\mathrm{mg} / \mathrm{mL})$, and the linear correlation coefficient is $\mathrm{r}=0.9959$. The method has been applied to the determination of cysteine in food, and the results are basically consistent with those determined by pharmacopoeial method.

\section{Experimental}

\subsection{Equipment and reagents}

UV-2401 UV-visible spectrophotometer (The Shimadzu Corporation,Japan); 722S spectrophotometer (Shanghai Precision \& Scientific Instrument Co,.Ltd ).

$\mathrm{Cu}^{2+}$ solution: $1.000 \mathrm{~g} / \mathrm{L}$, prepared by $\mathrm{CuSO}_{4} \cdot 5 \mathrm{H}_{2} \mathrm{O}$; Cysteine standard solution: $1.000 \mathrm{~g} / \mathrm{L}$; BOC solution: $1.000 \mathrm{~g} / \mathrm{L} ; \mathrm{pH}=9.18$ buffer solution: prepared by solium borate.

All reagents are of analytical reagent grade, and bidistilled water are used.

\footnotetext{
Corresponding author: 198601012@jyu.edu.cn
} 


\subsection{Method}

$1.000 \mathrm{~g} / \mathrm{L}$ cysteine standard solution $(1.00 \mathrm{~mL})$ or cysteine sample solution(appropriate amount), $1.000 \mathrm{~g} / \mathrm{L} \mathrm{Cu}^{2+}$ solution $(0.80 \mathrm{~mL}), 1.000 \mathrm{~g} / \mathrm{L}$ BOC solution $(4.00 \mathrm{~mL})$ and $\mathrm{pH}=9.18$ buffer solution $(3.20 \mathrm{~mL})$ are transferred into a comparison tube $(25 \mathrm{~mL})$. The mixed solution is diluted to $25 \mathrm{~mL}$ with distilled water, mixed well. In another comparison tube $(25 \mathrm{~mL})$, the blank solution $\left(\mathrm{Cu}^{2+}\right.$ solution $+\mathrm{BOC}$ solution $+\mathrm{pH}=9.18$ buffer solution) is prepared in the same way. Then the two solutions are reacted for $30 \mathrm{~min}$ at $85^{\circ} \mathrm{C}$ in water both and cooled back to room temperature. After placing $20 \mathrm{~min}$, the absorbance $\left(\mathrm{A}_{1}\right)$ of the blank solution $\left(\mathrm{Cu}^{2+}\right.$ solution $+\mathrm{BOC}$ solution $+\mathrm{pH}=9.18$ buffer solution) and the absorbance $\left(\mathrm{A}_{2}\right)$ of the determination solution(cysteine solution $+\mathrm{Cu}^{2+}$ solution $+\mathrm{BOC}$ solution $+\mathrm{pH}=9.18$ buffer solution) are measured at $602 \mathrm{~nm}$ using water as reference. The $\triangle A\left(\mathrm{~A}_{1}-\mathrm{A}_{2}\right)$ is calculated.

\section{Results and discussion}

\subsection{Absorption spectrum}

On the basis experimental method, the absorption spectrums of the blank solution $\left(\mathrm{Cu}^{2+}\right.$ solution+BOC solution $+\mathrm{pH}=9.18$ buffer solution) and the determination solution (cysteine solution $+\mathrm{Cu}^{2+}$ solution $+\mathrm{BOC}$ solution $+\mathrm{pH}=9.18$ buffer solution) in the range of $520 \sim 680 \mathrm{~nm}$ are shown in Figure 2. It can be seen that the maximum absorption wavelength of the blank solution and the determination solution are at $602 \mathrm{~nm}$. So, $602 \mathrm{~nm}$ is selected for determination wavelength.

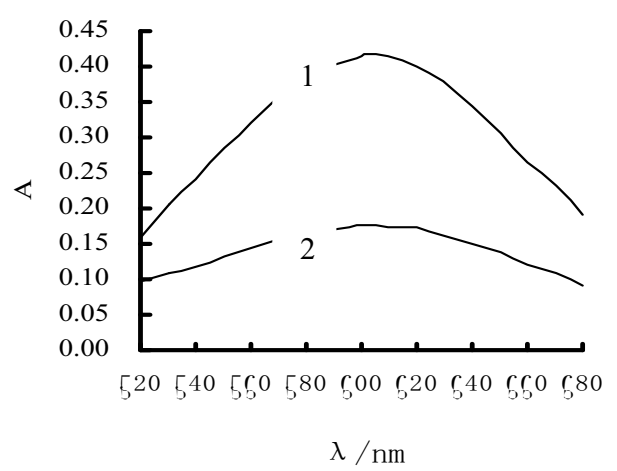

Fig. 2. Absorption spectrum 1-the blank solution $\left(\mathrm{Cu}^{2+}\right.$ solution+BOC solution+ $\mathrm{pH}=9.18$ buffer solution);

2-the determination solution (cysteine solution $+\mathrm{Cu}^{2+}$ solution $+\mathrm{BOC}$ solution $+\mathrm{pH}=9.18$ buffer solution);

Cysteine solution: $1.00 \mathrm{~mL} ; \mathrm{Cu}^{2+}$ solution:0.80 mL; BOC solution:4.00 mL; $\mathrm{pH}=9.18$ buffer solution:3.20 mL; reaction temperature: $85^{\circ} \mathrm{C}$; reaction time: $30 \mathrm{~min}$; placing time: $20 \mathrm{~min}$.

\subsection{Reaction temperature, reaction time and placing time}

The effect of the reaction temperature $\left(70 \sim 100^{\circ} \mathrm{C}\right)$ on the absorbance $(\triangle A)$ is seen in Figure 3. Figure 3 show that the $\triangle A$ of solution reaches maximum value and maintain basically stability when the temperature is $80 \sim$ $90^{\circ} \mathrm{C}$. So, $85^{\circ} \mathrm{C}$ is chosen.

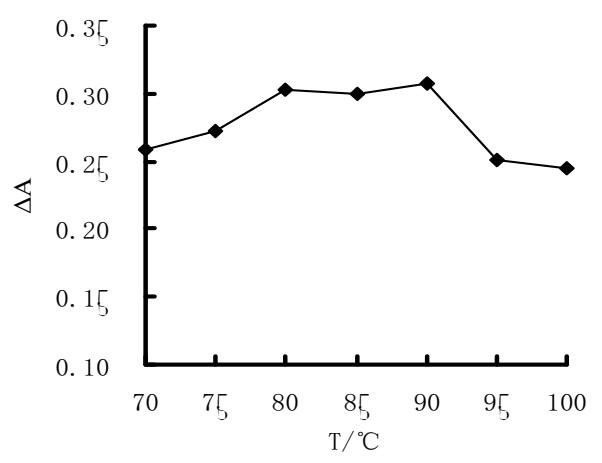

Fig. 3. Effect of the reaction temperature

Cysteine solution: $1.00 \mathrm{~mL}$; $\mathrm{Cu}^{2+}$ solution: $0.80 \mathrm{~mL}$; BOC solution:4.00mL; $\mathrm{pH}=9.18$ buffer solution: $3.20 \mathrm{~mL}$; reaction time:30min; placing time: $20 \mathrm{~min}$.

Keep other parameters constant, when the reaction temperature is $85^{\circ} \mathrm{C}$, the effect of the reaction time $(10 \sim$ $60 \mathrm{~min})$ on the absorbance $(\triangle A)$ is studied. The results show that the $\triangle A$ of solution reach maximum value and are basically identical when the reaction time is $20 \sim 30$ min. hence, $25 \mathrm{~min}$ is selected.

Keep other parameters constant, When the reaction temperature is $35^{\circ} \mathrm{C}$ and the reaction time is $25 \mathrm{~min}$, the effect of the placing time $(10 \sim 180 \mathrm{~min})$ is researched. The experiments show that the absorbance $(\triangle A)$ of solution reach maximum value and remain constant when the placing time is $30 \sim 60 \mathrm{~min}$. Therefore, $35 \mathrm{~min}$ is used.

\section{$3.3 \mathrm{pH}=9.18$ buffer solution amount}

The effect of the $\mathrm{pH}=9.18$ buffer solution amount on absorbance $(\triangle A)$ can be seen in Figure 4. The results show that the $\triangle \mathrm{A}$ reaches its larger value and when the $\mathrm{pH}=9.18$ buffer solution amount is up to $2.60 \mathrm{~mL}$. Furthermore, the $\triangle \mathrm{A}$ do not change with a further increase in the dosage of $\mathrm{pH}=9.18$ buffer solution. Hence, 2.80 $\mathrm{mL}$ of the $\mathrm{pH}=9.18$ buffer solution amount is chosen. 


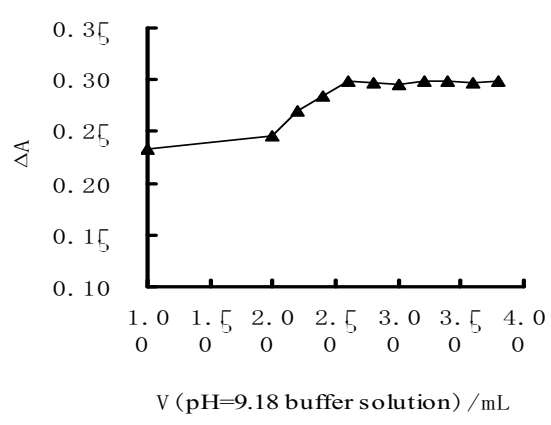

Fig. 4. Effect of $\mathrm{pH}=9.18$ buffer solution amount Cysteine solution: $1.00 \mathrm{~mL}$; $\mathrm{Cu}^{2+}$ solution:0.80mL; BOC solution: $4.00 \mathrm{~mL}$; reaction temperature: $85^{\circ} \mathrm{C}$; reaction time: 25min; placing time: $35 \mathrm{~min}$.

\section{$3.4 \mathrm{Cu}^{2+}$ solution amount}

The effect of $\mathrm{Cu}^{2+}$ solution amount on absorbance $(\triangle \mathrm{A})$ is discussed (Figure 5). We can seen from Figure 5 that the $\triangle \mathrm{A}$ attain maximum value and maintain basic stability when the $\mathrm{Cu}^{2+}$ solution amount is $0.50 \mathrm{~mL} \sim$ $0.80 \mathrm{~mL}$. So, $0.60 \mathrm{~mL} \mathrm{Cu}^{2+}$ solution is applied.

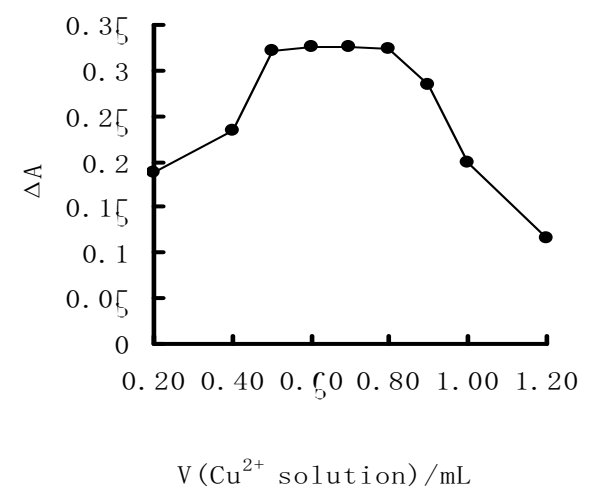

Fig. 5. Effect of $\mathrm{Cu}^{2+}$ solution amount

Cysteine solution: $1.00 \mathrm{~mL}$; BOC solution:4.00 mL; $\mathrm{pH}=9.18$ buffer solution: $2.80 \mathrm{~mL}$; reaction temperature: $85^{\circ} \mathrm{C}$; reaction time: $25 \mathrm{~min}$; placing time: $35 \mathrm{~min}$.

\subsection{BOC solution amount}

The effect of BOC solution amount on absorbance $(\triangle \mathrm{A})$ can be seen Figure 6 . Figure 6 show that the $\triangle \mathrm{A}$ run up to maximum value and keep basically unchanged when the BOC solution amount is $3.40 \mathrm{~mL} \sim 4.40 \mathrm{~mL}$. So, $3.60 \mathrm{~mL}$ BOC solution is employed in the subsequent studies.

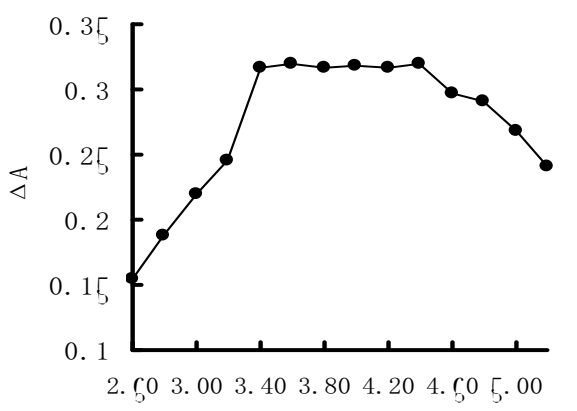

$\mathrm{V}($ BOC solution $) / \mathrm{mL}$

Fig. 6. Effect of BOC solution amount Cysteine solution: $1.00 \mathrm{~mL} ; \mathrm{Cu}^{2+}$ solution:0.60 mL; $\mathrm{pH}=9.18$ buffer solution: $2.80 \mathrm{~mL}$; reaction temperature: $85^{\circ} \mathrm{C}$; reaction time: $25 \mathrm{~min}$; placing time: $35 \mathrm{~min}$.

\subsection{Calibration curve}

Under the best selected conditions, a series of standard solutions of cysteine standard solution are prepared. The absorbance $(\triangle A)$ is measured at $602 \mathrm{~nm}$ according to the experimental method, then the calibration curve is drawed(Figure 7, concentration of cysteine standard solution at horizontal coordinates, $\triangle A$ at vertical coordinates). In the range of $0.008000 \sim 0.06800 \mathrm{mg} / \mathrm{mL}$, the linear regression equation is $\triangle A=0.2162+2.4842 C$ $(\mathrm{mg} / \mathrm{mL})$, and the correlation coefficient is 0.9992 .

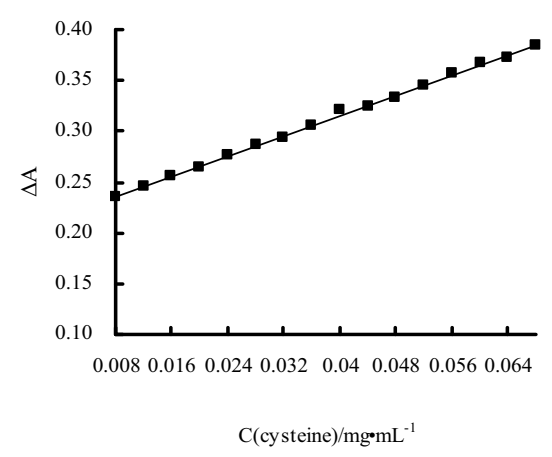

Fig. 7. Calibration curve

Cysteine solution: $1.00 \mathrm{~mL}$; $\mathrm{Cu}^{2+}$ solution: $0.60 \mathrm{~mL}$; BOC solution:3.60 mL; $\mathrm{pH}=9.18$ buffer solution: $2.80 \mathrm{~mL}$; reaction temperature: $85^{\circ} \mathrm{C}$; reaction time: $25 \mathrm{~min}$; placing time: $35 \mathrm{~min}$.

\subsection{Determination of food grade cysteine}

$0.0500 \mathrm{~g}$ power of food grade cysteine is weighed, then the power is dissolved in bidistilled water and is transferred into a $100 \mathrm{~mL}$ volumetric flask, the solution is diluted to the $100.0 \mathrm{~mL}$ and mixed well. This is the food grade cysteine sample solution.

Under the optimal conditions $\left(\mathrm{Cu}^{2+}\right.$ solution: $0.60 \mathrm{~mL}$; BOC solution:3.60 mL; $\mathrm{pH}=9.18$ buffer solution:2.80 $\mathrm{mL}$; reaction temperature: $85^{\circ} \mathrm{C}$; reaction time: $25 \mathrm{~min}$; placing time:35 $\mathrm{min}$ ), $1.60 \mathrm{~mL}$ food grade cysteine 
sample solution are added. The content of the food grade cysteine is determined by proposed method, and content of the food grade cysteine is determined by standard method also. Meanwhile, the recovery tests of standard addition are performed. The results as show in Table 1.

Table 1. The determination results of food grade cysteine $n=5$

\begin{tabular}{|c|c|}
\hline Sample & Food grade cysteine \\
\hline Proposed method $\left(\mathrm{mg} \cdot \mathrm{g}^{-1}\right)$ & 971.1 \\
\hline RSD $(\%)$ & 1.8 \\
\hline Standard method $\left(\mathrm{mg} \cdot \mathrm{g}^{-1}\right)$ & 973.5 \\
\hline \multirow{2}{*}{ Added $\left(\mu \mathrm{g} \cdot \mathrm{mL}^{-1}\right)$} & 8.000 \\
\multirow{2}{*}{ Recovered $\left(\mu \mathrm{g} \cdot \mathrm{mL}^{-1}\right)$} & 16.00 \\
\hline \multirow{2}{*}{ Recovery $(\%)$} & 7.568 \\
& 15.22 \\
\hline
\end{tabular}

\section{Conclusion}

A new method for the determination of cysteine by discoloration spectrophotometry using Copper( II )-biscyclohexanone oxalyldihydrazone (BCO) has been established. The determination result(content of food grade cysteine) by this proposed method consistent with the result by standard method. Obviously, this method has certain practical significance.

\section{References}

1. Liu, C.Y., Miao, Y.Q., Zhang, X.J., et al. (2020) Colorimetric determination of cysteine by a paperbased assay system using aspartic acid modified gold nanoparticles[J]. Microchemica.Anal., 187: 362.

2. Isachenko, A.I., Apyari, P.A., Dmitrienko, S.G., et al. (2020) Determination of cysteine by diffuse reflectance spectroscopy by its influence on the formation of gold nanocomposites based on polyurethane foam[J]. J.Anal. Chem., 75(7): 890-895.

3. Karimi, A., Husain, S.W., Hosseini M., et al. (2020) A sensitive signal-on electrochemiluminescence sensor based on a nanocomposite of polypyrrole- $\mathrm{Gd}_{2} \mathrm{O}_{3}$ for the determination of L-cysteine in biological fluids $[\mathrm{J}]$. Microchemica.Anal., 187: 398.

4. Cheng, T., Huang, W., Gao D., et al. (2019) Michael addition/S,N-intramolecular rearrangement sequence enables selective fluorescence detection of cysteine and homocysteine[J]. Anal.Chem., 91: 10894-10900.

5. Cao, N., Zhao, H., Tan, H., et al. (2019) Turn-on fluorescence detection of cysteine with glutathione protected silver nanoclusters[J]. Methods. Appl. Fluoresc., 7: 034004.

6. Nolin, T. D., Mcmenamin, M.E., Himmelfarb, J. (2007) Simultaneous determination of total homocysteine, cysteine, cysteinylglycine, and glutathione in human plasma by high-performance liquid chromatography: application to studies of oxidative stress[J]. J.Chromatogr B., 852: 554-561. 